\title{
ANTESEDEN LOYALITAS MEREK PADA PERUSAHAAN TOKOPEDIA.COM
}

\author{
Sarah Yulinar Adiputri ${ }^{1}$ \\ I Made Wardana ${ }^{2}$ \\ ${ }^{1,2}$ Fakultas Ekonomi dan Bisnis Universitas Udayana (Unud), Bali, Indonesia \\ email: sarahylnra@yahoo.com
}

\begin{abstract}
ABSTRAK
Tujuan dari penelitian ini adalah untuk meneliti pengaruh komunikasi merek, citra merek dan kepercayaan merek terhadap loyalitas merek. Penelitian ini dilakukan terhadap pengguna Tokopedia.com di Kabupaten Badung dan Kota Denpasar. Sampel penelitian adalah sebanyak 85 responden. Kuisioner menjadi sarana pengumpulan data pada penelitian ini. Teknik pengolahan data dalam penelitian ini adalah Partial Least Squares (PLS). Berdasarkan hasil pengolahan data diketahui bahwa komunikasi merek memiliki pengaruh yang positif signifikan terhadap citra merek. Komunikasi merek tidak memiliki pengaruh terhadap kepercayan merek. Citra merek memiliki pengaruh yang positif signifikan terhadap kepercayaan merek. Kepercayaan merek memiliki pengaruh yang positif signifikan terhadap loyalitas merek.
\end{abstract}

Kata kunci: komunikasi merek, citra merek, kepercayaan merek, loyalitas merek.

\section{ABSTRACT}

The purpose of this study was to examine the effect of brand communication, brand image and brand trust on brand loyalty. This research was conducted on Tokopedia.com users in Badung Regency and Denpasar City. The study sample was 85 respondents. Questionnaires became a means of collecting data in this study. The data processing technique in this study is Partial Least Squares (PLS). Based on the results of data processing it is known that brand communication has a significant positive effect on brand image. Brand communication has no influence on brand trust. Brand image has a significant positive effect on brand trust. Brand trust has a significant positive effect on brand loyalty.

Keywords: brand communication, brand image, brand trust, brand loyalty. 


\section{PENDAHULUAN}

Perkembangan teknologi di masa sekarang telah berkembang dengan pesat. Teknologi kini tidak hanya memudahkan dalam berkomunikasi saja, tetapi juga dalam mengakses informasi, bertransaksi perbankan, dan juga berbelanja online. Belanja online telah berkembang secara dramatis dalam satu dekade terakhir untuk hampir semua jenis barang, mulai dari buku, pakaian hingga bahan makanan (Maat dan Konings, 2018), sehingga banyak orang lebih memilih untuk berbelanja online dibandingkan berbelanja secara tradisional. Hal ini dapat disebabkan oleh terbatasnya waktu yang dimiliki, kemudahan yang ditawarkan oleh penjual online dan perkembangan teknologi yang sangat pesat.

Berdasarkan data survei mengenai Penetrasi \& Perilaku Pengguna Internet Indonesia Tahun 2017 yang diperoleh dari APJII (Asosiasi Penyelenggara Jasa Internet Indonesia) dari 262 juta warga Indonesia, 54,68 persen atau sebanyak 143,26 juta orang menggunakan internet. Berdasarkan jumlah tersebut, 32,19 persen menggunakan internet untuk melakukan transaksi beli online dan sebanyak 16,83 persen menggunakan internet untuk melakukan transaksi jual online.

Melihat adanya peluang dalam berbelanja online, Tokopedia hadir di Indonesia sebagai salah satu platform marketplace berbasis online terbesar di Indonesia yang mempertemukan jutaan pedagang dan konsumen dalam satu platform sehingga dapat terjadi proses jual-beli. Tokopedia menyediakan sarana bagi individu, kelompok maupun UMKM untuk menjual produk kepada masyarakan Indonesia secara online dan memfasilitasi konsumen untuk dapat memilih dan membeli produk secara online. Tokopedia didirikan oleh William Tanuwijaya dan Leontinus Alpha Edison pada 6 Februari 2009 dan resmi diluncurkan ke publik pada tanggal 17 Agustus 2009. Sejak resmi diluncurkan, Tokopedia berhasil menjadi salah satu perusahaan e-commerce Indonesia dengan pertumbuhan yang sangat pesat. Tokopedia berhasil menjadi salah satu perusahaan e-commerce Indonesia dengan pertumbuhan yang sangat pesat. Pada tanggal 11 Desember 2014, Tokopedia berhasil meraih penghargaan Marketeers of the Year 2014 untuk sektor e-Commerce pada acara Markplus Conference 2015 yang digelar oleh Markplus Inc. Pada 12 Mei 2016, Tokopedia terpilih sebagai Best Company in Consumer Industry dari Indonesia Digital Economy Award 2016.

Seiring berjalannya waktu, semakin banyak pilihan dan alternatif produk yang tidak terbatas, dengan beragam harga, kualitas, kelebihan dan pelayanan yang ditawarkan oleh berbagai perusahaan baik dari dalam maupun luar negeri yang dapat diperoleh konsumen. Hal ini menyebabkan banyaknya perusahaan yang menjadi head to head competitior dengan Tokopedia. Banyaknya platform ecommerce di Indonesia membuat perusahaan iPrice melakukan riset mengenai $e$ commerce unggulan di Indonesia dan riset tersebut didasari oleh jumlah kunjungan ke website tiap bulannya, ranking aplikasi, jumlah pengikut di media sosial, hingga jumlah karyawan. Riset yang dilakukan oleh iPrice mendapatkan hasil bahwa terdapat 5 perusahaan yang menjadi unggulan dalam bidang $e$ commerce yaitu, Tokopedia, Lazada, Bukalapak, Blibli dan Shopee. Penjelasan mengenai faktor-faktor yang menjadi dasar pemberian peringkat oleh iPrice dijabarkan dalam tabel berikut. 
Tabel 1.

Riset iPrice Mengenai Peringkat e-Commerce di Indonesia Tahun 2018

\begin{tabular}{|c|c|c|c|c|c|}
\hline & Lazada & Tokopedia & Bukalapak & Blibli & Shopee \\
\hline $\begin{array}{l}\text { Jumlah } \\
\text { Kunjungan } \\
\text { Website } \\
\text { Jumlah }\end{array}$ & 117,5 juta & 117,2 juta & 93 juta & 45 juta & 34,5 juta \\
\hline $\begin{array}{l}\text { Pengikut di } \\
\text { Social } \\
\text { Media }\end{array}$ & $\begin{array}{c}23.601 .000 \\
\text { orang }\end{array}$ & $\begin{array}{l}5.552 .000 \\
\text { orang }\end{array}$ & $\begin{array}{l}2.389 .000 \\
\text { orang }\end{array}$ & $\begin{array}{l}7.937 .000 \\
\text { orang }\end{array}$ & $\begin{array}{l}9.741 .000 \\
\text { orang }\end{array}$ \\
\hline $\begin{array}{l}\text { Jumlah } \\
\text { Karyawan }\end{array}$ & 1.479 orang & 1.611 orang & 1.233 orang & 797 orang & 1.129 orang \\
\hline $\begin{array}{l}\text { Peringkat } \\
\text { aplikasi di } \\
\text { Google } \\
\text { PlayStore }\end{array}$ & 3 & 2 & 4 & 5 & 1 \\
\hline $\begin{array}{l}\text { Peringkat } \\
\text { aplikasi di } \\
\text { Apple Store }\end{array}$ & 4 & 2 & 3 & 6 & 1 \\
\hline
\end{tabular}

Survei tahunan yang dikeluarkan oleh Frontier Consulting Group yaitu TBA (Top Brand Award) juga menjadi salah satu sumber data dalam penelitian ini. Top brand award adalah suatu penghargaan yang diberikan kepada merek-merek terbaik di Indonesia yang berpredikat TOP yang memenuhi kriteria tertentu. Data Top Brand Award adalah sebagai berikut.

Tabel 2.

Top Brand Award Kategori Situs Jual Beli Online

Periode 2016-2018

\begin{tabular}{lcccc}
\hline $\begin{array}{l}\text { Situs Jual Beli } \\
\text { Online }\end{array}$ & $\begin{array}{c}\text { Tahun } \\
\text { 2016(\%) }\end{array}$ & $\begin{array}{c}\text { Tahun } \\
\text { 2017 }(\%)\end{array}$ & $\begin{array}{c}\text { Tahun } \\
2018(\%)\end{array}$ & Kategori \\
\hline Lazada & 19,9 & 18,0 & 31,8 & TOP \\
Tokopedia & 12,1 & 13,4 & 18,5 & TOP \\
Bukalapak & 11,8 & 6,8 & 8,7 & - \\
Shopee & - & - & 14,7 & - \\
\hline
\end{tabular}

Sumber: Top Brand Award, 2018

Berdasarkan data yang telah diperoleh, menunjukkan bahwa Tokopedia berada di peringkat kedua setelah Lazada. Tokopedia merupakan pioneer dalam perusahaan e-commerce di Indonesia yang didirikan pada tahun 2009 sedangkan Lazada sebagai kompetitornya di Indonesia didirikan pada tahun 2012. Tokopedia tidak menjadi yang paling banyak digunakan oleh konsumen Indonesia sedangkan kompetitor dari Tokopedia yaitu Lazada menjadi yang paling banyak digunakan oleh konsumen Indonesia.

Tingginya persaingan dalam suatu industri menjadi permasalahan bagi perusahaan, sehingga perusahaan akan mencoba untuk membangun strategi untuk 
bertahan dari persaingan yaitu dengan menciptakan loyalitas. Dengan menciptakan loyalitas, pemasar menciptakan hubungan yang kuat dan erat dengan pelanggan yang merupakan impian pemasar dan sering menjadi kunci kesuksesan pemasaran jangka panjang (Kotler and Keller, 2012: 141).

Loyalitas merek telah didefinisikan sebagai pembelian berulang, preferensi, komitmen, sebagai retensi dan kesetiaan (Gounaris dan Stathakopoulos, 2004). Loyalitas merek memberikan keuntungan bagi pemasar dalam hal biaya, karena biaya untuk menghasilkan pelanggan baru jauh lebih banyak daripada biaya mempertahankan konsumen yang ada (Dehdashti et al., 2012; Noyan dan Şimşek, 2014; Wierich dan Zielke, 2014). Loyalitas merek menciptakan banyak keuntungan bagi pemilik merek seperti peningkatan market share, return on inverstment yang lebih tinggi sehingga menyebabkan munculnya keunggulan kompetitif dan menjadi penghalang bagi kompetitor dalam persaingan bisnis (Denoue and Saykiewicz, 2009).

Banyak peneliti telah mengemukakan berbagai faktor sebagai anteseden loyalitas merek. Berdasarkan penelitian yang dilakukan oleh Ha et al. (2011) bahwa iklan berpengaruh positif terhadap loyalitas merek, dengan peran mediasi yang dimainkan oleh citra toko, persepsi kualitas dan kepuasan konsumen. Komunikasi merek berfungsi untuk mengekspos merek kepada masyarakat hingga menciptakan citra merek yang positif kepada masyarakat.

Beberapa peneliti di dalam penelitian yang dilakukan telah mengungkapkan bahwa citra merek memiliki pengaruh terhadap loyalitas merek (Gul et al., 2010). Diungkapkan pula oleh Aydin dan Özer (2005) bahwa citra merek memiliki pengaruh yang tinggi terhadap konsumen daripada kualitas fisik produk dalam mendeterminasi apakah mereka akan membeli produk yang sama dikemudian hari. Zakladna dan Ehrl (2011) juga mengungkapkan bahwa daya tarik citra merek terhadap citra diri konsumen menjadi dasar untuk membangun hubungan antara pelanggan dan merek, yang pada akhirnya menjadi dasar bagi loyalitas merek.

Citra merek tidak hanya menciptakan daya tarik bagi kosumen tetapi juga menciptakan kepercayaan merek. Penciptaan citra sebuah merek dianggap penting karena menjadi langkah awal untuk memulai kepercayaan konsumen terhadap sebuah merek (Dewi, 2014). Kepercayaan adalah harapan pihak yang terlibat dalam transaksi dan risiko yang terkait dengan harapan dan perilaku (Rai dan Medha, 2013; Atkinson dan Rosenthal, 2014). Kepercayaan dapat mengurangi ketidakpastian konsumen, karena konsumen tidak hanya tahu bahwa merek dapat dipercaya, namun juga berpikir bahwa skenario konsumsi yang andal, aman dan jujur adalah link penting dari kepercayaan merek (Upamannyu dan Mathur, 2012).

Melihat permasalahan yang terjadi ini maka dilakukan penelitian mengenai antesedan dari loyalitas merek untuk mengetahui faktor-faktor pendahulu yang dapat menyebabkan loyalitas merek pada perusahaan Tokopedia. Berdasarkan latar belakang masalah yang telah diuraikan diatas, rumusan masalah dari penelitian ini adalah sebagai berikut. 1) Apakah komunikasi merek berpengaruh terhadap citra merek perusahaan Tokopedia. 2) Apakah komunikasi merek berpengaruh terhadap kepercayaan merek perusahaan Tokopedia. 3) Apakah citra merek berpengaruh terhadap kepercayaan merek perusahaan Tokopedia. 4) 
Apakah kepercayaan merek berpengaruh terhadap loyalitas merek perusahaan Tokopedia.

Hasil penelitian ini diharapkan menambah bukti empiris tentang studi yang membahas hubungan antara loyalitas merek, komunikasi merek, citra merek dan kepercayaan merek. Hasil dari penelitian ini diharapkan mampu memberikan gambaran dan pemahaman yang jelas bagi perusahaan terkait dengan hal-hal apa sajakah yang patut diperhatikan apabila menjalankan suatu konsep bisnis yang berkaitan dengan loyalitas konsumen pada perusahaan Tokopedia sebagai dasar untuk meningkatkan loyalitas konsumen dari perusahaan Tokopedia.

Komunikasi merek adalah elemen integratif utama dalam mengelola hubungan merek dengan pelanggan, karyawan, pemasok, anggota saluran, media, regulator pemerintah, dan masyarakat (Zehir et al., 2011). Komunikasi merek juga termasuk menciptakan dan memainkan peran penting dalam membangun hubungan merek dengan pelanggan dan tujuannya adalah untuk mengekspos pelanggan terhadap merek yang dapat meningkatkan kesadaran dan ingatan pelanggan sehingga pelanggan akan membeli merek tersebut yang memiliki ingatan tertinggi (Etemadifard et al., 2013). Citra merek adalah serangkaian asosiasi unik di benak pelanggan mengenai apa yang dimiliki oleh merek dan tersiratnya janji yang dibuat merek (Neupane, 2015). Citra merek telah didefinisikan sebagai gambaran mental konsumen tentang penawaran dan mencakup makna simbolis yang dikaitkan konsumen dengan atribut spesifik dari produk atau layanan (Salinas dan Pérez, 2009; Bibby, 2011).

Menurut Delgado (2003), kepercayaan merek didefinisikan sebagai perasaan keamanan yang dimiliki oleh konsumen dalam interaksi dengan merek, didasarkan pada persepsi bahwa merek tersebut dapat diandalkan dan bertanggung jawab atas kepentingan dan kesejahteraan konsumen. Hubungan mendalam antara perusahaan dan pelanggan meningkatkan potensi pelanggan untuk berbagi informasi rahasia dan pribadi mereka dengan merek (Krom, 2015). Loyalitas merek dianggap sebagai salah satu konstruksi kunci pada sebagian besar konseptualisasi ekuitas merek konsumen (Veloutsou et al., 2013). Konsep loyalitas merek didefinisikan sebagai sikap positif individu yang diulang dalam jangka waktu terhadap produk sebuah merek (Baig et al., 2015). Loyalitas merek dapat diukur melalui kata positif dari word of mouth, kepuasan pelanggan, kepercayaan merek, kepekaan harga, dll (Ahmed, 2014). Loyalitas merek menghasilkan banyak keuntungan seperti membangun hambatan pada pesaing, menghasilkan penjualan dan pendapatan yang lebih besar, mengurangi biaya akuisisi pelanggan, dan menghambat kerentanan pelanggan terhadap usaha pemasaran pesaing.

Dalam menciptakan loyalitas merek pelanggan, organisasi harus memberi arti penting pada citra merek (Momen et al., 2014). Dalam penelitian Chinomona (2016) menyebutkan tujuan komunikasi merek adalah untuk mengkomunikasikan atribut yang relevan yang dapat memuaskan atau memenuhi kebutuhan batin konsumen serta secara keseluruhan menumbuhkan citra merek di benak para pelanggan. Toha (2016) melakukan penelitian mengenai pengaruh komunikasi merek dan citra merek terhadap kepercayaan merek Semen Tiga Roda di Jawa Timur dan mendapatkan hasil bahwa komunikasi merek memiliki pengaruh positif 
terhadap citra merek dan komunikasi merek berperan sebagai tolak ukur terciptanya citra merek. Berdasarkan kajian empiris sebelumnya, maka dapat disusun hipotesis sebagai berikut.

$\mathrm{H}_{1}$ : Komunikasi merek berpengaruh positif signifikan terhadap citra merek

Dalam penelitian Zehir (2011), temuan penelitian menunjukkan bahwa komunikasi merek sebagai platform untuk menciptakan dan mengembangkan hubungan berbasis kepercayaan antara merek dan pelanggan.dan terdapat hubungan positif antara komunikasi merekdan kepercayaan merek. Hasil penelitian oleh Etemadifard et al. (2013) menunjukkan bahwa variabel komunikasi merek memiliki hubungan erat dengan kepercayaan merek dan komunikasi merek memiliki dampak langsung dan positif pada kepercayaan merek.

Toha (2016) melakukan penelitian dan mendapatkan hasil bahwa variabel komunikasi merek merupakan tolak ukur terciptanya kepercayaan merek. Komunikasi merek memiliki pengaruh positif dan signifikan terhadap kepercayaan merek. Sehingga dapat disimpulkan bahwa semakin baik komunikasi merek akan meningkatkan kepercayaan merek semen Tiga Roda di Jawa Timur. Berdasarkan kajian empiris sebelumnya, maka dapat disusun hipotesis sebagai berikut.

$\mathrm{H}_{2}$ : Komunikasi merek berpengaruh positif signifikan terhadap kepercayaan merek

Citra merek terdiri dari asosiasi konsumen dengan kelebihan dan karakteristik pribadi dari produk merek (Farida dan Ardyan, 2015). Semuel dan Lianto (2014) melakukan penelitian dan mendapatkan hasil bahwa citra merek yang positif akan menyebabkan kenaikan pada kepercayaan merek. Siwandana dan Wardana (2017) menyatakan dalam penelitiannya bahwa green brand image berpengaruh signifikan dan positif terhadap green trust. Hasil penelitian menunjukkan bahwa semakin baik persepsi konsumen mengenai citra dari produk ramah lingkungan, maka potensi kepercayaan konsumen akan produk dengan klaim ramah lingkungan juga akan semakin tinggi. Rodiques dan Rahanatha (2018) dalam penelitiannya menunjukkan bahwa citra merek secara positif dan signifikan berpengaruh terhadap kepercayaan merek pada konsumen Iphone di Kota Denpasar. Berdasarkan kajian empiris sebelumnya, maka dapat disusun hipotesis sebagai berikut.

$\mathrm{H}_{3}$ : Citra merek berpengaruh positif signifikan terhadap kepercayaan merek

Kepercayaan merek adalah hal yang penting yang membantu pelanggan setia terhadap merek. Tanpa kepercayaan pada brand, customer tidak bisa masuk dalam set loyalitas (Ahmed, 2014). Kepercayaan merek membangun hubungan abadi yang sangat dihargai antara merek dan konsumen, dan merupakan salah satu faktor penentu loyalitas merek yang penting (Bianchi et al., 2014). Ayu dan Sulistyawati (2018) dalam penelitiannya menyatakan bahwa kepercayaan merek berpengaruh positif dan signifikan terhadap loyalitas pelanggan berbelanja di Zalora Online shop. Kepercayaan akan suatu merek bagi konsumen akan mampu 
memberikan dampak positif dan signifikan dalam menciptakan loyalitas pelanggan.

Dalam studi Liao (2015), hasil penelitian menunjukkan bahwa kepercayaan merek memiliki peran mediator dalam menjembatani pengaruh pendahulunya terhadap loyalitas merek dan ekuitas merek serta studi ini lebih lanjut menemukan bahwa kepercayaan merek adalah faktor yang penting untuk meningkatkan loyalitas merek dan ekuitas merek. Oleh karena itu, kepercayaan merek memiliki pengaruh yang positif terhadap loyalitas merek. Berdasarkan kajian empiris sebelumnya, maka dapat disusun hipotesis sebagai berikut.

$\mathrm{H}_{4}$ : Kepercayaan merek berpengaruh positif signifikan terhadap loyalitas merek

\section{METODE PENELITIAN}

Jenis penelitian ini digolongkan ke dalam penelitian asosiatif yaitu hubungan antara variabel komunikasi merek mempengaruhi citra merek dan kepercayaan merek, hubungan antara variabel citra merek mempengaruhi kepercayaan merek serta hubungan antara variabel kepercayaan merek mempengaruhi loyalitas merek pada pengguna e-commerce Tokopedia di Kabupaten Badung dan Kota Denpasar.

Objek dalam penelitian ini adalah variabel-variabel yang diteliti dalam penelitian ini,sedangkan subjek dalam penelitian ini adalah pengguna $e$ commerceTokopedia yang pernah melakukan pembelian atau mengunjungi $e$ commerce Tokopedia di Kabupaten Badung dan Kota Denpasar. Populasi dalam penelitian ini adalah masyarakat Kabupaten Badung dan Kota Denpasar yang merupakan pengguna Tokopedia dan jumlahnya tidak dapat di tentukan secara pasti. Sampel yang diambil dalam penelitian ini adalah konsumen perusahaan Tokopedia. Metode penentuan sampel yang digunakan dalam penelitian ini adalah non probability sampling. Teknik yang digunakan adalah purposive sampling. Kriteria yang digunakan dalam menentukan responden pada penelitian ini adalah konsumen perusahaan Tokopedia dengan rentang umur 18-60 tahun yang berpendidikan minimum SMA yang berdomisili di Kabupaten Badung dan Kota Denpasar dan memilih Tokopedia sebagai pilihan utamanya saat ingin berbelanja.

Data kualitatif dalam penelitian ini berupa pendapat dari responden terhadap pertanyaan dalam kuesioner. Data kuantitatif dalam penelitian ini berupa data mengenai persentase situs berbelanja online yang ada di Indonesia tahun 20162018 berdasarkan peringkat Top Brand Indonesia beserta hasil riset yang dilakukan oleh perusahaan iPrice mengenai e-commerce unggulan di Indonesia. Sumber data primer dalam penelitian ini adalah tanggapan responden dalam kuesioner penelitian. Sumber data sekunder dalam penelitian ini adalah institusi atau pihak lain yang mempublikasikan data yang dikutip terkait dengan topik penelitian ini.

Data dalam penelitian ini metode pengumpulan data berupa penyebaran kuisioner yang secara langsung disebarkan oleh peneliti. Pengujian validitas dan reliabilitas dilakukan agar kuesioner layak untuk digunakan sebagai sumber data. Data dikumpulkan dari 30 orang responden yang memenuhi kriteria atau pertimbangan yang telah ditentukan untuk melakukan pengujian validitas dan realibilitas. Uji validitas instrument memiliki rumus sebagai berikut. 


$$
r_{x y}=\frac{n \Sigma X Y-(\Sigma X \cdot \Sigma Y)}{\sqrt{\left[n \Sigma X^{2}-\left(\Sigma X^{2}\right)\right]\left[n \Sigma Y^{2}-\left(\Sigma Y^{2}\right)\right.}}
$$

Keterangan:

$r_{x y} \quad=$ koefisien korelasi

$\mathrm{n} \quad=$ banyaknya sampel

$\Sigma X Y=$ jumlah perkalian variabel $\mathrm{x}$ dan $\mathrm{y}$

$\Sigma X \quad=$ jumlah nilai variabel $\mathrm{x}$

$\Sigma Y \quad=$ jumlah nilai variabel $\mathrm{y}$

Pengujian realibilitas memiliki rumus sebagai berikut.

$$
\alpha=\frac{k}{k-1}\left(1-\frac{\Sigma \sigma_{i}^{2}}{\sigma_{x}^{2}}\right)
$$

Keterangan:

$\alpha \quad=$ korelasi variabel

$k \quad=$ jumlah pertanyaan

$\sigma_{i}^{2} \quad=$ variansi setiap pertanyaan

$\sigma_{x}^{2} \quad=$ variansi total tes

$\Sigma \sigma_{i}^{2}=$ jumlah seluruh variansi setiap pertanyaan

Teknik analisis statistik deskriptif mendeskripsikan karakteristik responden dan variabel-variabel penelitian. Statistik deskriptif adalah statistik yang digunakan untuk menganalisis data dengan cara mendeskripsikan data yang telah terkumpul untuk membuat kesimpulan (Sugiyono, 2014 :169). Statistik deskriptif berupa rata-rata usia responden dan rata-rata skor jawaban dari kuesioner. Ratarata skor jawaban responden pada kuesioner dikelompokkan kedalam 5 kelas interval (Wirawan, 2002 :35).

Analisis statistik inferensial digunakan untuk menguji hipotesis dan untuk membuat kesimpulan yang berlaku untuk populasi (Sugiyono, 2014:147). Dalam penelitian ini digunakan Partial Least Squares (PLS) untuk menguji hipotesis dan membuat kesimpulan dari hipotesis tersebut. PLS merupakan metode analisis yang diperkenalkan oleh Herman Wold dan sering disebut soft modeling. Dengan penggunaan PLS, pemodelan persamaan struktural dapat dilakukan dengan ukuran sampel yang relatif kecil dan tidak membutuhkan asumsi normal multivariate. Evaluasi model dalam PLS terdiri dari dua tahap, yaitu evaluasi outer model atau model pengukuran dan evaluasi inner model atau model struktural (Ghazali, 2006).

Model pengukuran (outer model) sering juga disebut outer relation atau measurement model yang mendefinisikan bagaimana setiap blok indikator berhubungan dengan variabel latennya. Model pengukuran (outer model) digunakan untuk menilai validitas dan realibilitas model. Uji validitas terbagi atas 2 jenis, yaitu validitas konvergen dan validitas diskriminan. Pengujian validitas konvergen dilakukan dengan 3 kriteria teknis analisis data pada PLS untuk menilai outer model yaitu convergent validity, average variance extracted (AVE), serta discriminant validity (Putra et al., 2018). Pengujian realibilitas dapat dilakukan dengan melihat nilai dari cronbach's alpha dan nilai composite realibility 
Model struktural (inner model) merupakan model struktural untuk memprediksi hubungan kausalitas antar variabel laten. Evaluasi inner model juga bertujuan untuk mengetahui goodness of fit dengan menggunakan beberapa metode seperti R-squares, Q-squares, Path Coefficient, dan F-squares.

\section{HASIL DAN PEMBAHASAN}

Karakteristik responden penelitian memaparkan profil dari 85 responden yang telah melakukan pengisian kuesioner penelitian ini. Profil responden terdiri dari jenis kelamin, usia, pendidikan terakhir dan pekerjaan. Karakteristik responden dipaparkan secara rinci dalam tabel 3. sebagai berikut.

Tabel 3.

Karakteristik Responden

\begin{tabular}{|c|c|c|c|c|}
\hline No & Karakteristik & Klasifikasi & $\begin{array}{c}\text { Jumlah } \\
\text { Orang }\end{array}$ & $\begin{array}{c}\text { Persentase } \\
(\%)\end{array}$ \\
\hline \multirow[t]{3}{*}{1} & Jenis Kelamin & Laki-laki & 40 & 47 \\
\hline & & Perempuan & 45 & 53 \\
\hline & Jumlah & & 85 & 100 \\
\hline \multirow[t]{5}{*}{2} & Usia & 19-23 Tahun & 69 & 81 \\
\hline & & 24-28 Tahun & 4 & 5 \\
\hline & & 29-33 Tahun & 6 & 7 \\
\hline & & $>34$ Tahun & 6 & 7 \\
\hline & Jumlah & & 85 & 100 \\
\hline \multirow[t]{5}{*}{3} & Pendidikan Terakhir & SMA / Sederajat & 42 & 49 \\
\hline & & Diploma & 20 & 24 \\
\hline & & Sarjana & 17 & 20 \\
\hline & & Pascasarjana & 6 & 7 \\
\hline & Jumlah & & 85 & 100 \\
\hline \multirow[t]{6}{*}{4} & Pekerjaan & Pelajar & 42 & 49 \\
\hline & & $\mathrm{PNS} / \mathrm{ASN}$ & 10 & 12 \\
\hline & & Wiraswasta & 21 & 25 \\
\hline & & Karyawan & 8 & 10 \\
\hline & & Lainnya & 4 & 4 \\
\hline & Jumlah & & 85 & 100 \\
\hline
\end{tabular}

Berdasarkan data yang diperoleh dari tabel 3., diketahui bahwa pada kriteria jenis kelamin responden didominasi oleh responden perempuan dengan jumlah persentase sebesar 53 persen dan diikuti dengan responden laki-laki dengan jumlah persentase sebesar 47 persen. Pada kriteria usia responden didominasi oleh responden dengan rentang usia 19-23 tahun dengan persentase sebesar 81 persen dan persentase terendah dimiliki oleh responden dengan rentang usia 24-28 tahun dengan persentase sebesar 5 persen. Kriteria pendidikan terakhir didominasi oleh responden dengan pendidikan terakhir tingkat SMA/Sederajat dengan persentase sebesar 49 persen dan persentase terendah dimiliki oleh responden dengan pendidikan terakhir tingkat pascasarjana dengan persentase sebesar 7 persen. Kriteria pekerjaan didominasi oleh reponden dengan pekerjaan sebagai pelajar dengan persentase sebesar 49 persen dan persentase terendah dimiliki oleh 
responden dengan pekerjaan dengan kategori lainnya yaitu dengan persentase sebesar 4 persen.

Tabel 4.

Hasil Uji Validitas Instrumen Penelitian

\begin{tabular}{|c|c|c|c|c|}
\hline Variabel & & Indikator & $\begin{array}{c}\text { Pearson } \\
\text { Correlation }\end{array}$ & $\begin{array}{c}\text { Ketera } \\
\text { ngan }\end{array}$ \\
\hline \multirow{3}{*}{$\begin{array}{l}\text { Komunikasi } \\
\text { Merek }\end{array}$} & $\mathrm{X}_{1}$ & Rasa senang terhadap & 0,878 & Valid \\
\hline & & promosi merek & & \\
\hline & $\mathrm{X}_{2}$ & $\begin{array}{l}\text { Konsumen mengingat } \\
\text { promosi merek }\end{array}$ & 0,886 & Valid \\
\hline \multirow{3}{*}{$\begin{array}{l}\text { Komunikasi } \\
\text { Merek }\end{array}$} & $\mathrm{X}_{3}$ & Promosi merek menarik & 0.946 & Valid \\
\hline & & perhatian & 0,943 & Valid \\
\hline & $\mathrm{X}_{4}$ & $\begin{array}{l}\text { Promosi merek menarik } \\
\text { niat beli }\end{array}$ & & \\
\hline \multirow[t]{5}{*}{ Citra Merek } & $\mathrm{Y}_{1.1}$ & $\begin{array}{l}\text { Layanan yang ditawarkan } \\
\text { oleh merek memiliki fitur } \\
\text { yang lebih baik }\end{array}$ & 0,917 & Valid \\
\hline & $\mathrm{Y}_{1.2}$ & Citra merek bagus & 0,910 & Valid \\
\hline & $\mathrm{Y}_{1.3}$ & $\begin{array}{l}\text { Kepribadian merek yang } \\
\text { membedakan merek dari } \\
\text { pesaing }\end{array}$ & 0,727 & Valid \\
\hline & $\mathrm{Y}_{1.4}$ & $\begin{array}{l}\text { Merek tidak } \\
\text { mengecewakan }\end{array}$ & 0,844 & Valid \\
\hline & $\mathrm{Y}_{1.5}$ & $\begin{array}{l}\text { Merek tersebut adalah } \\
\text { salah satu merek terbaik di } \\
\text { sektor tersebut }\end{array}$ & 0,858 & Valid \\
\hline \multirow[t]{4}{*}{$\begin{array}{l}\text { Kepercayaan } \\
\text { Merek }\end{array}$} & $\mathrm{Y}_{2.1}$ & $\begin{array}{l}\text { Rasa percaya terhadap } \\
\text { merek }\end{array}$ & 0,939 & Valid \\
\hline & $\mathrm{Y}_{2.2}$ & $\begin{array}{l}\text { Merek diandalkan } \\
\text { konsumen }\end{array}$ & 0,883 & Valid \\
\hline & $\mathrm{Y}_{2.3}$ & Merek dianggap jujur & 0,937 & Valid \\
\hline & $\mathrm{Y}_{2.4}$ & $\begin{array}{l}\text { Merek tersebut merupakan } \\
\text { aman }\end{array}$ & 0,890 & Valid \\
\hline \multirow[t]{4}{*}{ Loyalitas Merek } & $\mathrm{Y}_{3.1}$ & $\begin{array}{l}\text { Konsumen selalu memilih } \\
\text { merek yang sama }\end{array}$ & 0,931 & Valid \\
\hline & $\mathrm{Y}_{3.2}$ & $\begin{array}{l}\text { Merek tersebut merupakan } \\
\text { pilihan pertama konsumen }\end{array}$ & 0,919 & Valid \\
\hline & $\mathrm{Y}_{3.3}$ & $\begin{array}{l}\text { Konsumen } \\
\text { merekomendasikan merek } \\
\text { kepada orang lain }\end{array}$ & 0,857 & Valid \\
\hline & $\mathrm{Y}_{3.4}$ & $\begin{array}{l}\text { Konsumen bersedia } \\
\text { membayar harga yang } \\
\text { lebih tinggi untuk merek } \\
\text { tersebut dibandingkan } \\
\text { merek lain }\end{array}$ & 0,894 & Valid \\
\hline
\end{tabular}

Sumber: Data primer diolah, 2018

Pengujian validitas instrument dilakukan terhadap 30 responden dan pengujian validitas dilakukan dengan menghitung Pearson Correlation. Suatu instrumen dapat dikatakan valid apabila r Pearson Correlation terhadap skor total diatas 0,30 . Berdasarkan data yang diperoleh dari tabel 4. dapat diketahui bahwa seluruh instrumen penelitian ini memiliki hasil Pearson Correlation yang lebih 
besar dari 0,30. Oleh karena itu, seluruh instrumen penelitian ini adalah valid sehingga dapat dikatakan layak sebagai instrumen penelitian.

Tabel 5.

Hasil Uji Realibilitas Instrumen Penelitian

\begin{tabular}{lcc}
\hline \multicolumn{1}{c}{ Variabel } & Cronbach's Alpha & Keterangan \\
\hline Komunikasi Merek & 0,843 & Reliabel \\
Citra Merek & 0,815 & Reliabel \\
Kepercayaan Merek & 0,840 & Reliabel \\
Loyalitas Merek & 0,839 & Reliabel \\
Sumber: Data primer diolah, 2018 & &
\end{tabular}

Pengujian reliabilitas instrumen penelitian dilakukan terhadap 30 responden dan pengujian realibilitas instrumen dilakukan dengan melihat nilai Cronbach's Alpha dari masing-masing variabel penelitian. Instrumen dikatakan reliabel apabila koefisien Cronbach's Alpha $\geq 0,6$. Berdasarkan data yang diperoleh dari tabel 5 dapat diketahui bahwa seluruh instrumen penelitian dalam variabel komunikasi merek, citra merek, kepercayaan merek dan loyalitas merek memiliki hasil Cronbach's Alpha yang lebih besar dari 0,6. Oleh karena itu, dapat disimpulkan bahwa semua instrumen penelitian ini adalah reliabel sehingga dapat dikatakan layak sebagai instrumen penelitian.

Tabel 6.

Outer Loadings

\begin{tabular}{lccccc}
\hline & $\begin{array}{c}\text { Original } \\
\text { Sample } \\
(\mathbf{O})\end{array}$ & $\begin{array}{c}\text { Sample } \\
\text { Mean } \\
(\mathbf{M})\end{array}$ & $\begin{array}{c}\text { Standard } \\
\text { Deviation } \\
\text { (STDEV) }\end{array}$ & $\begin{array}{c}\text { T Statistics } \\
(\mathbf{O} / \mathbf{S T D E V}\end{array}$ & P Values \\
\hline CM1<-CM & 0,833 & 0,834 & 0,041 & 20,492 & 0,000 \\
CM2<-CM & 0,781 & 0,778 & 0,044 & 17,891 & 0,000 \\
CM3<-CM & 0,639 & 0,639 & 0,063 & 10,154 & 0,000 \\
CM4<-CM & 0,827 & 0,830 & 0,036 & 22,758 & 0,000 \\
CM5<-CM & 0,829 & 0,828 & 0,041 & 20,196 & 0,000 \\
KM1<-KM & 0,828 & 0,828 & 0,040 & 20,604 & 0,000 \\
KM2<-KM & 0,845 & 0,846 & 0,027 & 31,607 & 0,000 \\
KM3<-KM & 0,880 & 0,877 & 0,028 & 31,184 & 0,000 \\
KM4<-KM & 0,840 & 0,837 & 0,044 & 19,264 & 0,000 \\
KOM1<-KOM & 0,855 & 0,854 & 0,032 & 27,117 & 0,000 \\
KOM2<-KOM & 0,810 & 0,807 & 0,056 & 14,535 & 0,000 \\
KOM3<-KOM & 0,874 & 0,874 & 0,036 & 24,393 & 0,000 \\
KOM4<-KOM & 0,849 & 0,846 & 0,034 & 25,140 & 0,000 \\
LM1<-LM & 0,896 & 0,894 & 0,026 & 34,776 & 0,000 \\
LM2<-LM & 0,899 & 0,896 & 0,023 & 39,880 & 0,000 \\
LM3<-LM & 0,810 & 0,812 & 0,050 & 16,354 & 0,000 \\
LM4<-LM & 0,802 & 0,804 & 0,047 & 16,947 & 0,000 \\
\hline Sumber - Data primer diolah, 2018 & & & &
\end{tabular}


Berdasarkan data yang diperoleh dari tabel 6 diketahui bahwa nilai original sample seluruh indikator yang digunakan pada penelitian ini mendapatkan hasil diatas 0,5 , sehingga nilai outer model dapat dikatakan telah memenuhi kriteria convergent validity. Nilai $\mathrm{P}$ values yang diperoleh seluruh indikator mendapakan hasil lebih kecil dari 0,05 , sehingga nilai outer model dapat dikatakan telah memenuhi kriteria convergent validity.

Tabel 7.

Nilai Average Variance Extracted (AVE)

\begin{tabular}{lcr}
\hline & AVE & Akar AVE \\
\hline Komunikasi Merek & 0,718 & 0,847 \\
Citra Merek & 0,617 & 0,785 \\
Kepercayaan Merek & 0,720 & 0,849 \\
Loyalitas Merek & 0,728 & 0,853 \\
\hline
\end{tabular}

Sumber: Data primer diolah, 2018

Berdasarkan data yang diperolah dari Tabel 7. diketahui bahwa seluruh variabel yang digunakan dalam penelitian ini mendapatkan hasil diatas 0,5 , sehingga nilai AVE dapat dikatakan telah memenuhi kriteria convergent validity.

Tabel 8.

Cross Loading

\begin{tabular}{ccccc}
\hline & $\begin{array}{c}\text { Citra } \\
\text { Merek }\end{array}$ & $\begin{array}{c}\text { Kepercayaan } \\
\text { Merek }\end{array}$ & $\begin{array}{c}\text { Komunikasi } \\
\text { Merek }\end{array}$ & $\begin{array}{c}\text { Loyalitas } \\
\text { Merek }\end{array}$ \\
\hline CM1 & 0,833 & 0,588 & 0,623 & 0,755 \\
CM2 & 0,781 & 0,592 & 0,619 & 0,650 \\
CM3 & 0,639 & 0,387 & 0,509 & 0,427 \\
CM4 & 0,827 & 0,684 & 0,374 & 0,561 \\
CM5 & 0,829 & 0,583 & 0,489 & 0,552 \\
KM1 & 0,586 & 0,828 & 0,461 & 0,463 \\
KM2 & 0,706 & 0,845 & 0,533 & 0,719 \\
KM3 & 0,557 & 0,880 & 0,275 & 0,514 \\
KM4 & 0,593 & 0,840 & 0,400 & 0,556 \\
KOM1 & 0,623 & 0,540 & 0,855 & 0,546 \\
KOM2 & 0,510 & 0,301 & 0,810 & 0,411 \\
KOM3 & 0,591 & 0,418 & 0,874 & 0,484 \\
KOM4 & 0,533 & 0,406 & 0,849 & 0,495 \\
LM1 & 0,683 & 0,567 & 0,537 & 0,896 \\
LM2 & 0,695 & 0,602 & 0,532 & 0,899 \\
LM3 & 0,658 & 0,595 & 0,492 & 0,810 \\
LM4 & 0,554 & 0,545 & 0,399 & 0,802 \\
\hline
\end{tabular}

Sumber: Data primer diolah, 2018

Berdasarkan data yang diperoleh dari Tabel 8. diketahui bahwa nilai cross loading menunjukkan adanya discriminant validity yang baik. Hal tersebut dapat dilihat dari nilai korelasi indikator terhadap konstruknya (loading factor) lebih 
tinggi dibandingkan nilai korelasi indikator tersebut dengan konstruk lainnya.

Tabel 9.

Korelasi Antar Konstruk

\begin{tabular}{|c|c|c|c|c|}
\hline & CM & KM & KOM & LM \\
\hline $\mathrm{CM}$ & 1,000 & & & \\
\hline $\mathrm{KM}$ & 0,728 & 1,000 & & \\
\hline KOM & 0,670 & 0,502 & 1,000 & \\
\hline LM & 0,762 & 0,678 & 0,576 & 1,000 \\
\hline
\end{tabular}

Berdasarkan data yang diperoleh dari Tabel 9. diketahui bahwa nilai square root of average variance extracted (AVE) yaitu $0,785,0,849,0,848,0,853$ lebih besar dari korelasi masing-masing konstruk. Oleh karena itu, dapat disimpulkan bahwa model penelitian ini memiliki discriminant validity yang baik.

Tabel 10.

Cronbach's Alpha dan Composite Realibility

\begin{tabular}{lcc}
\hline \multicolumn{1}{c}{ Variabel } & $\begin{array}{c}\text { Cronbach's } \\
\text { Alpha }\end{array}$ & $\begin{array}{c}\text { Composite } \\
\text { Realibility }\end{array}$ \\
\hline Komunikasi Merek & 0,870 & 0,911 \\
Citra Merek & 0,842 & 0,889 \\
Kepercayaan Merek & 0,871 & 0,911 \\
Loyalitas Merek & 0,874 & 0,914 \\
Sumber: Data primer diolah, 2018 & &
\end{tabular}

Berdasarkan data yang diperoleh dari tabel 10 diketahui bahwa nilai cronbach's alpha yang diperoleh seluruh variabel memiliki nilai lebih dari 0,6, sehingga dapat disimpulkan bahwa seluruh variabel pada penelitian ini dapat dikatakan reliabel. Nilai composite realibility yang diperoleh seluruh varibel memiliki nilai lebih dari 0,7 , sehingga dapat disimpulkan bahwa seluruh variabel pada penelitian ini dapat dikatakan reliabel.

Tabel 11.

R-squares

\begin{tabular}{lcc}
\hline \multicolumn{1}{c}{ Variabel } & \multicolumn{1}{c}{ R- } & P \\
& squares & Values \\
\hline Komunikasi Merek & 0,449 & 0,000 \\
Citra Merek & 0,531 & 0,000 \\
Kepercayaan Merek & 0,460 & 0,000 \\
Loyalitas Merek &
\end{tabular}

Berdasarkan data yang diperoleh dari Tabel 11. diketahui bahwa model penelitian dapat dikatakan signifikan karena nilai $\mathrm{P}$-values yang diperoleh variabel lebih kecil dari alpha 0,05 dan nilai $\mathrm{R}^{2}$ variabel citra merek sebesar 0,449 yang dapat diinterpretasikan bahwa 44,9 persen variabilitas citra merek dijelaskan oleh variabel komunikasi merek, sedangkan 55,1 persen variabel citra merek dijelaskan oleh variabel di luar model. Nilai $\mathrm{R}^{2}$ variabel kepercayaan merek sebesar 0,531 
yang dapat diinterpretasikan bahwa 53,1 persen variabilitas kepercayaan merek dijelaskan oleh variabel komunikasi merek, sedangkan 46,9 persen variabel kepercayaan merek dijelaskan oleh variabel diluar model. Nilai $\mathrm{R}^{2}$ variabel loyalitas merek sebesar 0,460 dapat diinterpretasikan bahwa 46 persen variabilitas loyalitas merek dijelaskan oleh variabel komunikasi merek, sedangkan 54 persen variabel loyalitas merek dijelaskan oleh variabel diluar model.

Q-Squares (Predictive Relevance) digunakan untuk mengukur nilai observasi yang dihasilkan oleh model estimasi dan parameternya Perhitungan nilai Q-squares pada penelitian ini dilakukan sebagai berikut.

$$
\begin{array}{ll}
\mathrm{Q}^{2} & =1-\left(1-\mathrm{R}^{2}{ }_{1}\right)\left(1-\mathrm{R}^{2}{ }_{2}\right)\left(1-\mathrm{R}^{2}{ }_{3}\right) \ldots \ldots \ldots \\
\mathrm{Q}^{2} & =1-(1-0,449)(1-0,531)(1-0,460) \\
\mathrm{Q}^{2} & =1-(0,551)(0,461)(0,54) \\
\mathrm{Q}^{2} & =1-0,14 \\
\mathrm{Q}^{2} & =0,86 \\
\mathrm{Q}^{2} & =86 \%
\end{array}
$$

Berdasarkan hasil perhitungan yang dilakukan maka didapatkah hasil nilai Q-squares sebesar 86 persen yang dapat diartikan bahwa model penelitian memiliki nilai observarsi yang baik. Hasil nilai sebesar 86 persen berarti bahwa hubungan antar variabel dapat dijelaskan oleh model penelitian yang dilakukan. Oleh karena itu, dapat disimpulkan berdasarkan perhitungan nilai $\mathrm{R}^{2}$ dan $\mathrm{Q}^{2}$ bahwa kriteria model penelitian dikategorikan sebagai model penelitian yang kuat dan baik, sehingga dapat dilanjutkan dengan analisis pengujian hipotesis.

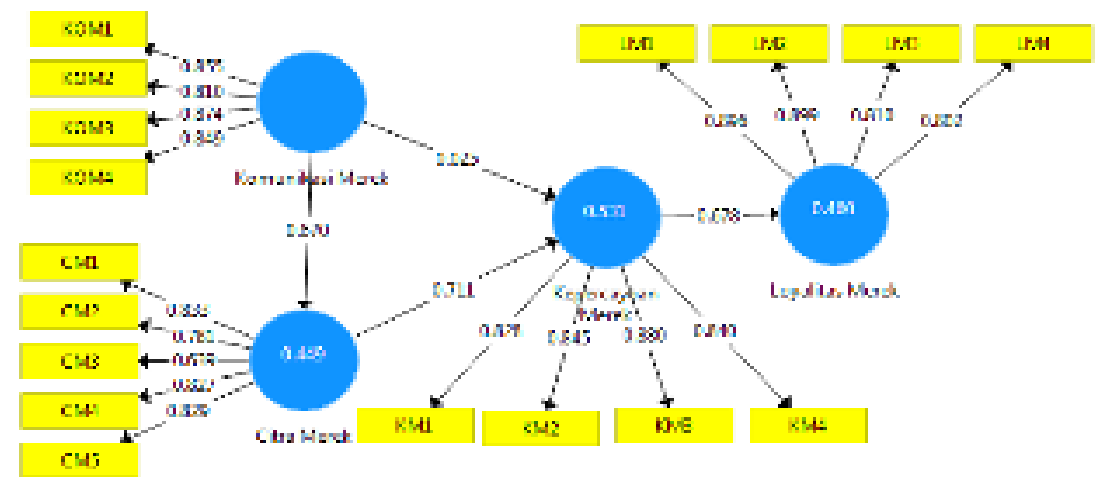

Gambar 1.

Diagram Jalur Model Analisis

Sumber: Data primer diolah, 2018

Model struktural diatas disebut sebagai model reflektif dimana covariance pengukuran indikator dipengaruhi oleh konstruk laten atau mencerminkan variasi dari konstruk unidimensional yang digambarkan dengan bentuk elips dengan beberapa anak panah dari konstruk ke indikator. Model ini menghipotesiskan bahwa perubahan pada konstruk laten akan mempengaruhi perubahan pada indikator. 
Tabel 12.

Path Coefficient (Mean, STDEV, T-Values)

\begin{tabular}{lccccc}
\hline & $\begin{array}{c}\text { Original } \\
\text { Sample (O) }\end{array}$ & $\begin{array}{c}\text { Sample } \\
\text { Mean } \\
(\boldsymbol{M})\end{array}$ & $\begin{array}{c}\text { Standard } \\
\text { Deviation } \\
(\text { STDEV })\end{array}$ & $\begin{array}{c}\text { TStatistics } \\
(\text { OS/STERR })\end{array}$ & $\begin{array}{c}\boldsymbol{P} \\
\text { Values }\end{array}$ \\
\hline $\mathrm{CM}$-> KM & 0,711 & 0,711 & 0,097 & 7,306 & 0,000 \\
$\mathrm{KM}->\mathrm{LM}$ & 0,678 & 0,689 & 0,059 & 11,470 & 0,000 \\
$\mathrm{KOM}->\mathrm{CM}$ & 0,670 & 0,672 & 0,075 & 8,902 & 0,000 \\
$\mathrm{KOM}->\mathrm{KM}$ & 0,025 & 0,031 & 0,108 & 0,235 & 0,815 \\
\hline
\end{tabular}

Sumber: Data primer diolah, 2018

Pada penelitian ini nilai T-tabel dengan signifikansi pa $\alpha=0,05$ dengan nilai T- Statistik lebih besar dari t-hitung $(1,989)$ ditetapkan sebagai dasar penilaian. Berdasarkan data yang diperoleh dari Tabel 12. diketahui bahwa tiga dari empat koefisien jalur memiliki nilai T-Statistik diatas 1,989 sehingga dapat diartikan bahwa koefisien jalur tersebut memiliki pengaruh yang signifikan, namun satu koefisien jalur memiliki nilai T-Statistik dibawah 1,989 sehingga dapat diartikan bahwa koefisien jalur tersebut tidak memiliki pengaruh yang signifikan. Nilai $\mathrm{P}$ Values yang diperoleh tiga dari koefisien jalur dibawah 0,05 sehingga dapat diartikan bahwa koefisien jalur memiliki pengaruh yang signifikan, namun satu koefisien jalur memiliki nilai P Values diatas 0,05 sehingga dapat diartikan bahwa koefisien jalur tersebut tidak memiliki pengaruh yang signifikan.

Tabel 13.

F-Squares

\begin{tabular}{lcc}
\hline & F-Squares & P Values \\
\hline Citra Merek -> Komunikasi Merek & 0,593 & 0,033 \\
Kepercayaan Merek -> Loyalitas Merek & 0,852 & 0,016 \\
Komunikasi Merek -> Citra Merek & 0,816 & 0,030 \\
Komunikasi Merek -> Kepercayaan Merek & 0,001 & 0,975 \\
\hline
\end{tabular}

Sumber: Data primer diolah, 2018

Berdasarkan data yang diperoleh dari Tabel 13. diketahui bahwa hubungan antara variabel citra merek dengan komunikasi merek adalah signifikan karena nilai P-Values lebih kecil dari alpha 0,05 dan memiliki efek yang kuat karena nilai effect size sebesar 0,593 yang merupakan kategori kuat. Hubungan antara variabel kepercayaan merek dengan loyalitas merek adalah signifikan karena nilai PValues lebih kecil dari alpha 0,05 dan memiliki efek yang kuat karena nilai effect size sebesar 0,852 yang merupakan kategori kuat. Hubungan antara variabel komunikasi merek dengan citra merek adalah signifikan karena nilai P-Values lebih kecil dari alpha 0,05 dan memiliki efek yang kuat karena nilai effect size sebesar 0,816 yang merupakan kategori kuat. Hubungan antara variabel komunikasi merek dengan kepercayaan merek adalah tidak signifikan karena nilai $\mathrm{P}$-Values lebih besar dari alpha 0,05 dan memiliki efek yang lemah karena nilai effect size sebesar 0,001 yang merupakan kategori lemah. 
Tabel 14.

Pengaruh Tidak Langsung

\begin{tabular}{lccccc}
\hline & $\begin{array}{c}\text { Original } \\
\text { Sample } \\
(\mathbf{O})\end{array}$ & $\begin{array}{c}\text { Sample } \\
\text { Mean } \\
(\mathbf{M})\end{array}$ & $\begin{array}{c}\text { Standard } \\
\text { Deviation } \\
(\text { STDEV) }\end{array}$ & $\begin{array}{c}\text { T Statistics } \\
(\mid \mathbf{O} / \mathbf{S T E R R})\end{array}$ & $\begin{array}{c}\text { P } \\
\text { Values }\end{array}$ \\
\hline $\mathrm{CM}$-> KM & & & & & \\
$\mathrm{CM}$-> LM & 0,482 & 0,492 & 0,088 & 5,481 & 0,000 \\
$\mathrm{KM} \mathrm{->} \mathrm{LM}$ & & & & & \\
$\mathrm{KOM}$-> CM & & & & & \\
$\mathrm{KOM}$-> KM & 0,477 & 0,479 & 0,088 & 5,410 & 0,000 \\
$\mathrm{KOM}$-> LM & 0,341 & 0,354 & 0,084 & 4,069 & 0,000 \\
\hline
\end{tabular}

Sumber: Data primer diolah, 2018

Data yang diperoleh dari Tabel 14. memberikan informasi dan memperkuat bahwa variabel citra merek berpengaruh signifikan terhadap variabel kepercayaan merek dan variabel kepercayaan merek berpengaruh signifikan terhadap variabel loyalitas merek, sehingga hubungan tidak langsung antara variabel citra merek terhadap variabel loyalitas merek adalah signifikan karena nilai P-Values lebih kecil dari 0,05. Dengan demikian dapat disimpulkan bahwa variabel kepercayaan merek dapat memediasi pengaruh variabel citra merek terhadap variabel loyalitas merek.

Tabel 14. juga memperkuat bahwa variabel komunikasi merek berpengaruh signifikan terhadap variabel citra merek dan variabel citra merek berpengaruh signifikan terhadap variabel kepercayaan merek, sehingga hubungan tidak langsung antara variabel komunikasi merek terhadap kepercayaan merek adalah signifikan karena nilai P-Values lebih kecil dari 0,05. Dengan demikian dapat disimpulkan bahwa variabel citra merek dapat memediasi pengaruh variabel komunikasi merek terhadap kepercayaan merek.

Tabel 14. juga memberikan informasi bahwa variabel komunikasi merek tidak berpengaruh signifikan terhadap variabel kepercayaan merek dan variabel kepercayaan merek berpengaruh signifikan terhadap variabel loyalitas merek, namun terdapat hubungan tidak langsung antara variabel komunikasi merek dengan loyalitas merek yang signifikan karena nilai P-Values lebih kecil dari 0,05. Dengan demikian dapat disimpulkan bahwa variabel kepercayaan merek dapat memediasi pengaruh variabel komunikasi merek terhadap loyalitas merek.

Tabel 15.

Nilai Path dan Uji Hipotesa

\begin{tabular}{|c|c|c|c|}
\hline Hubungan Variabel & Path & P-Values & Hipotesis \\
\hline $\mathrm{KOM}(\mathrm{X})->\mathrm{CM}\left(\mathrm{Y}_{1}\right)$ & 0,670 & 0,000 & Diterima \\
\hline $\mathrm{KOM}(\mathrm{X})->\mathrm{KM}\left(\mathrm{Y}_{2}\right)$ & 0,025 & 0,815 & Ditolak \\
\hline $\mathrm{CM}\left(\mathrm{Y}_{1}\right)->\mathrm{KM}\left(\mathrm{Y}_{2}\right)$ & 0,711 & 0,000 & Diterima \\
\hline $\mathrm{KM}\left(\mathrm{Y}_{2}\right)->\mathrm{LM}\left(\mathrm{Y}_{3}\right)$ & 0,678 & 0,000 & Diterima \\
\hline
\end{tabular}

Sumber: Data primer diolah, 2018

Berdasarkan data yang diperoleh dari tabel 15 diketahui bahwa tiga hubungan variabel memiliki hubungan yang positif signifikan dan terdapat satu 
hubungan variabel yang memiliki hubungan yang tidak signifikan, hal ini diketahui dengan melihat nilai P-Values yang didapatkan oleh setiap hubungan variabel. Suatu hubungan variabel dapat dikatakan positif signifikan apabila nilai $\mathrm{P}$-Values yang diperoleh hubungan variabel lebih kecil dari alpha 0,05 . Pengujian hipotesis dijelaskan lebih rinci sebagai berikut.

Hasil penelitian menunjukan bahwa komunikasi merek berpengaruh positif signifikan terhadap citra merek pengguna Tokopedia. Hasil pengujian sesuai dengan penelitian terdahulu yang dilakukan oleh Chinomona (2016) yang menyatakan bahwa komunikasi merek memiliki pengaruh positif yang signifikan pada konsumen di Provinsi Gauteng, Afrika Selatan. Penelitian yang dilakukan oleh Nurdianasari dan Indriani (2017) juga mendapatkan hasil positf signifikan yang berarti hasil positif signifikan variabel citra merek mengindikasikan bahwa semakin baik komunikasi merek yang diterapkan maka akan semakin kuat citra merek suatu produk.

Hasil penelitian menunjukan bahwa komunikasi merek tidak berpengaruh signifikan terhadap kepercayaan merek pengguna Tokopedia. Hasil pengujian sesuai dengan penelitian terdahulu yang dilakukan oleh Chinomona (2016) yang menyataka bahwa komunikasi merek tidak berpengaruh signifikan terhadap kepercayaan merek pada konsumen di Provinsi Gauteng, Afrika Selatan.

Hasil penelitian menunjukan bahwa citra merek berpengaruh positif signifikan terhadap kepercayaan merek pengguna Tokopedia. Hasil pengujian sesuai dengan penelitian terdahulu yang dilakukan oleh Semuel dan Lianto (2014) yang mendapatkan hasil bahwa citra merek yang positif akan menyebabkan kenaikan pada kepercayaan merek dan begitu juga sebaliknya jika citra merek jelek atau turun maka kepercayaan merek juga akan menurun yang dapat diartikan bahwa citra merek produk smartphone berpengaruh positif terhadap kepercayaan merek produk smartphone. Chinomona (2016) dalam penelitiaannya juga menyebutkan bahwa tingkat citra merek yang tinggi berkaitan dengan tingkat kepercayaan merek yang tinggi sehingga adanya hubungan yang positif dan signifikan antara citra merek dan kepercayaan merek. Rodiques dan Rahanatha (2018) dalam penelitiannya menunjukkan bahwa citra merek secara positif dan signifikan berpengaruh terhadap kepercayaan merek pada konsumen Iphone di Kota Denpasar yang dapat diartikan bahwa semakin baik citra merek yang dibentuk oleh suatu merek terhadap konsumen maka semakin tinggi kepercayaan merek yang dirasakan konsumen terhadap merek tersebut

Hasil penelitian menunjukan bahwa kepercayaan merek berpengaruh positif signifikan terhadap loyalitas merek pengguna Tokopedia. Hasil pengujian sesuai dengan penelitian terdahulu yang dilakukan oleh Ayu dan Sulistyawati (2018) dalam penelitiannya menyatakan bahwa kepercayaan merek berpengaruh positif dan signifikan terhadap loyalitas pelanggan berbelanja di Zalora Online shop. Kepercayaan akan suatu merek bagi konsumen akan mampu memberikan dampak positif dan signifikan dalam menciptakan loyalitas pelanggan. Liao (2015) juga mendapatkan hasil dalam penelitiannya bahwa kepercayaan merek adalah faktor yang penting untuk meningkatkan loyalitas merek dan ekuitas merek. Oleh karena 
itu, kepercayaan merek memiliki pengaruh yang positif terhadap loyalitas merek.

\section{SIMPULAN}

Berdasarkan tujuan penelitian, rumusan masalah dan hasil penelitian dengan pembahasan yang telah dijelaskan sebelumnya, maka dapat diambil beberapa kesimpulan sebagai berikut. Komunikasi merek berpengaruh secara positif signifikan terhadap citra merek. Komunikasi merek tidak memiliki pengaruh terhadap kepercayaan merek. Citra merek berpengaruh secara positif signifikan terhadap kepercayaan merek. Kepercayaan merek berpengaruh secara positif signifikan terhadap loyalitas merek. Variabel kepercayaan merek dapat memediasi pengaruh variabel citra merek terhadap variabel loyalitas merek. Variabel citra merek dapat memediasi pengaruh variabel komunikasi merek terhadap kepercayaan merek. Variabel kepercayaan merek dapat memediasi pengaruh variabel komunikasi merek terhadap loyalitas merek.

Berdasarkan hasil penelitian yang dilakukan, saran yang dapat diberikan kepada perusahaan Tokopedia dengan harapan dapat membantu perusahaan Tokopedia dan peneliti selanjutnya adalah sebagai berikut. Citra merek memiliki pengaruh yang besar dalam kepercayaan merek pelanggan Tokopedia. Oleh karena itu, baiknya perusahaan Tokopedia meningkatkan dan menjaga citra merek yang baik bagi perusahaan Tokopedia. Hal ini dapat dicapai dengan meningkatkan komunikasi merek Tokopedia ke pelanggan tetap maupun pelanggan baru perusahaan Tokopedia, sehingga dengan terciptanya citra merek yang baik, maka akan tercipta kepercayaan merek yang baik dari pelanggan ke perusahaan Tokopedia. Untuk penelitian selanjutnya diharapkan agar dapat melakukan penelitian dengan menambahkan variabel-variabel baru yang berpotensial dan dapat dijadikan anteseden dari loyalitas merek. Diharapkan penelitian selanjutnya dapat memperluas ruang lingkup dan memperbesar jumlah responden agar hasil penelitian dapat lebih representatif.

\section{REFERENSI}

Abdillah, Willy dan Jogiyanto. (2015). Partial Least Square (PLS) Alternatif Structural Equation Modeling (SEM) dalam Penelitian Bisnis. Ed.1. Yogyakarta: ANDI.

Ahmed, Zohaib dan Rizwan, Muhammad. (2014). Effect of brand trust and customer satisfaction on brand loyalty in Bahawalpur. Journal of Sociological Research, Vol. 5, No. 1.

Asosiasi Penyelenggara Jasa Internet Indonesia (APJII). (2017). Penetrasi \& Perilaku Pengguna Internet Indonesia Tahun 2017. https://apjii.or.id/survei2017/download/6KC4qnfbpjDTcJAlW3er7SsMLg 8V0U. Diakses 2 September 2018, 19:42.

Ayu, Dicka Puspita dan Eka Sulistyawati. (2018). Persepsi Nilai Pelanggan Memediasi Pengaruh Kepercayaan Merek Dan Kualitas Layanan Terhadap 
Loyalitas Pelanggan Berbelanja Online. E-Jurnal Manajemen Unud, Vol. 7, No. 5, hal. 2353-2379.

Baisya, Rajat K. (2013). Branding in a Competitive Marketplace. India: SAGE. Chinomona, Richard. (2016). Brand communication, brand image and brand trust as antecedents of brand loyalty in Gauteng Province of South Africa. African Journal of Economic and Management Studies, Vol. 7, No. 1, pp. 124-139.

Dwivedi, A., \& McDonald, R. (2018). Building brand authenticity in fast-moving consumer goods via consumer perceptions of brand marketing communications. European Journal of Marketing, 52(7/8), pp. 13871411 .

Farida, Naili dan Ardyan, Elia. (2015). Repeat Purchase Intention of Starbucks Consumers in Indonesia: A Green Brand Approach. TRŽIŠTE Journal of Croatian Association of Marketing Vol. 27, No. 2, 2015, pp. 189 - 202.

Ghazali, G. (2006). Structural Equation Modelling: Metode Alternatif dengan Partial Least Square. Badan Penerbit Universitas Diponegoro. Semarang.

Kotler, Philip dan Keller, Kevin. (2012). Marketing Management. New Jersey: Prentice Hall.

Krom, Ipek. (2015). Global Online Entrepreneurship and the Impact of Innovation on Brand. Emerging Market Journals, Volume 5 No 2 (2015), pp. 89-101.

Lien, C., Wen, M., Huang, L., Wu, K. (2015). Online hotel booking: The effects of brand image, price, trust and value on purchase intentions. Asia Pacific Management Review vol. 20, pp. 210-218

Martínez, P., Pérez, A., \& del Bosque, I. R. (2014). CSR influence on hotel brand image and loyalty. Academia Revista Latinoamericana de Administración, Vol. 27(2), pp. 267-283.

Maat, Kees and Konings, Rob. (2018). Accessibility or Innovation? Store Shopping Trips versus Online Shopping. Journal of Transportation Research Record, Vol.1 No.10 pp.1-10.

Nurdianasari, Rista dan Farida Indriani. (2017). Studi Mengenai Brand Communication, Brand Image dan Brand Trust Serta Pengaruhnya Terhadap Brand Loyalty Pada Produk Hand and Body Lotion Merek Citra. Diponegoro Journal of Management, Volume 6, Nomor 4, Halaman 1-14.

Putra, I Komang Satria Warla, Putu Yudi Setiawan dan Ni Nyoman Rsi Respati. (2018). Pengaruh Persepsi Negara Asal Terhadap Niat Beli Ulang 
Dimediasi Oleh Ekuitas Merek. E-Jurnal Manajemen Unud, Vol. 7, No. 7, Hal. 3974-4001.

Rodiques, Yolanda dan Gede Bayu Rahanatha. (2018). Peran Brand Trust Memediasi Hubungan Brand Image Dengan Brand Loyalty (Studi Pada Konsumen Iphone Di Kota Denpasar). E-Jurnal Manajemen Unud, Vol. 7, No. 3, Hal. 1310-1338.

Siwandana, I Komang Lowis, dan I Made Wardana (2017). Peran Green Trust Memediasi Pengaruh Green Brand Image Terhadap Green Brand Equity Pada Produk Hijau. E-Jurnal Manajemen Unud, Vol. 6, No. 4, 2017: 1789-1815.

Sugiyono. (2014). Metode Penelitian Pendidikan Pendekatan Kuantitatif, Kulitatif dan $R \& D$. Bandung : CV Alfabeta.

Taşkın, C., Emel, G., Karadamar, A., and Memiş, N. (2016). Exploring The Relationships Among the Antecedents of Brand Loyalty: A Research on an Apparel Brand. 3rd International Conference on Education, Social Sciences and Humanitie, pp. 366-376.

Tingkir, C.J. (2014). Pengaruh Identitas Merek Terhadap Loyalitas Merek Melalui Citra Merek Dan Kepercayaan Merek Toyota. Jurnal Manajemen Pemasaran, Vol. 8, No. 2, pp. 62-69.

Toha, Jessica. (2016). Analisis Pengaruh Brand Communication dan Brand Image Terhadap Brand Trust Semen Tiga Roda Di Jawa Timur. Jurnal Manajeman Pemasaran Vol 3, No 2.

Top Brand Award. (2018). Survey Top Brand Award. http://www.topbrandaward.com/top-brand-survey/survey-result/top_brand_index_2018_fase_2. Diakses 7 September 2018, 20:18.

Torres, Pedro Marcelo, Mário Gomes Augusto and João Veríssimo Lisboa. (2015). Determining the causal relationships that affect consumer-based brand equity the mediating effect of brand loyalty. Marketing Intelligence \& PlanningVol. 33 No. 6, pp. 944-956

Veloutsou, Cleopatra. (2015). Brand evaluation, satisfaction and trust as predictors of brand loyalty: the mediator-moderator effect of brand relationships. Journal of Consumer Marketing 32/6, pp. 405-421.

Wierich, R., Zielke, S. (2014). How retailer coupons increase attitudinal loyaltythe impact of three coupon design elements. European Journal of Marketing, 48(3/4), pp. 699-721. 
E-Jurnal Manajemen, Vol. 8, No. 9, 2019 :5421-5441

Wikipedia. (2018). Tokopedia. https://id.wikipedia.org/wiki/Tokopedia. Diakses 2 September 2018, 19:46.

Zakladna, U., Ehrl, M. (2011). Effect of the Chinese Acquisition on the Brand Image of Volvo Cars. Sweden: Mälardalen University. 